\title{
ANALISIS KESALAHAN SISWA SMP DALAM MENYELESAIKAN SOAL CERITA BERDASARKAN TAHAPAN NEWMAN PADA MATERI BANGUN DATAR SEGIEMPAT
}

\author{
Mochamad Andy Ardianzah \\ Jurusan Matematika, Program Studi Pendidikan Matematika, FMIPA, Universitas Negeri Surabaya, \\ email: mochamadardianzah@mhs.unesa.ac.id \\ Pradnyo Wijayanti \\ Pendidikan Matematika, FMIPA, Universitas Negeri Surabaya \\ e-mail: pradnyowijayanti@unesa.ac.id
}

\begin{abstract}
Abstrak
Dalam mengerjakan permasalahan matematika, pasti ada yang mengalami suatu hambatan dalam proses pemecahannya yang menyebabkan terjadinya suatu kesalahan dalam proses pembelajaran. Penelitian ini bertujuan untuk menganalisis jenis kesalahan yang dilakukan siswa dalam menyelesaikan soal cerita berdasarkan tahapan Newman pada materi bangun datar segiempat dan penyebab mereka melakukan kesalahan tersebut. Penelitian ini merupakan penelitian deskriptif-kualitatif dengan metode tes tulis dan wawancara. Subjek penelitian adalah 3 dari 32 siswa kelas VII-D SMP Negeri 2 Nganjuk yang dipilih berdasarkan banyaknya kesalahan yang dilakukan saat tes tulis. Hasil penelitian menunjukkan kesalahan yang dilakukan siswa dalam mengerjakan soal cerita tentang bangun datar segiempat, yaitu (1) kesalahan dalam membaca soal, (2) kesalahan dalam memahami soal, (3) kesalahan dalam mentransformasi soal, (4) kesalahan dalam keterampilan proses, dan (5) kesalahan dalam menuliskan jawaban akhir. Penyebab siswa melakukan kesalahan tersebut adalah siswa kurang teliti dalam membaca dan mengerjakan soal, belum paham materi dan belum terbiasa mengerjakan soal cerita dengan tahapan Newman.
\end{abstract}

Kata kunci: analisis, kesalahan, soal cerita, tahapan newman, bangun datar segiempat.

\begin{abstract}
In working on mathematical problems, there must be someone(s) who got some obstacles in the process of solving it which causes an error in the learning process. This research aims to describe students errors according to Newman's Error Analysis in solving rectangular word problem and why they are doing that. This research used a qualitative-descriptive approach with the written test and interview method. The research subjects were 3 of 32 students from class $8^{\text {th }}$-D Public Middle School 2 Nganjuk which is chosen based on the number of errors made during the written test. The results of this research shows that the students made some errors in solving mathematics involving rectangular word problems such as reading error, comperhension error, transformation error, process skill error and encoding error. The reason students make these mistakes are (1) students are not careful in reading and working on problems, (2) students doesn't understand the material, (3) and students are not usual to working on word problems using the Newman's method.
\end{abstract}

Keywords: analysis, errors, word problems, Newman's method, rectangular.

\section{PENDAHULUAN}

Matematika adalah cabang ilmu yang perlu diperhatikan dalam proses pembelajaran. Matematika perlu dipelajari, dipahami dan dikuasai oleh semua orang, karena matematika merupakan dasar ilmu dari semua cabang ilmu pengetahuan dan teknologi. Dalam kehidupan sehari-hari, matematika merupakan salah satu pengetahuan yang mempunyai peranan penting dalam memecahkan masalah. Hal ini dibuktikan dengan adanya perbedaan dalam mempelajari matematika sekolah dengan matematika secara umum di kehidupan sehari-hari (Ekawati, 2011). Matematika yang dipelajari di sekolah berorientasi pada pencapaian tujuan pendidikan atau pembelajaran matematika, salah satunya adalah mengembangkan keterampilan dalam memecahkan masalah.
Menurut Putri (2017), Kemampuan siswa dalam memecahkan permasalahan soal cerita bisa digunakan sebagai alat ukur untuk melihat seberapa besar kemampuan siswa tersebut dalam memecahkan suatu masalah matematika. Rahardjo dan Waluyati (2011) juga berpendapat bahwa Persoalan matematika baik dengan bentuk soal cerita maupun soal non-cerita dapat digunakan untuk mengukur tingkat kemampuan siswa dalam mata pelajaran matematika. Dengan demikian pemberian soal cerita pada siswa sangat berperan penting dalam meningkatkan keterampilan dan kemampuan matematika siswa. Hal tersebut dapat diperoleh siswa apabila guru mengajarkan siswa bagaimana memecahkan masalah soal cerita dengan baik dan efektif.

Dalam mengerjakan permasalahan matematika, pasti ada yang mengalami suatu hambatan dalam proses 
pemecahannya yang menyebabkan terjadinya suatu kesalahan dalam proses pembelajaran. Ada beberapa metode yang dapat digunakan dalam proses pemecahan masalah dengan bentuk soal cerita, seperti contoh, metode yang diungkapkan oleh Polya dan Newman.

Polya (1973) membagi tahapan pemecahan masalah menjadi 4 tahap, antara lain, memahami masalah (understanding the problem); merencanakan penyelesaian (devising a plan); melaksanakan rencana pemecahan masalah (carrying out the plan); memeriksa kembali (looking back). Sementara Newman (dalam White, 2005) menjelaskan tentang tahapan dalam memecahkan suatu permasalahan matematika berbentuk soal cerita. Tahapan Newman tersebut antara lain membaca (reading); memahami (comprehension); mentransformasi (transformation); keterampilan proses (process skill); dan penulisan jawaban akhir (encoding).

Perbedaan dari tahapan Polya dan Newman terletak pada tidak adanya tahap membaca pada tahapan Polya. Meski begitu tahapan Polya tidak jauh berbeda dengan tahapan Newman, karena bukan berarti dengan tidak adanya tahap membaca soal siswa tetap bisa memahami permasalahan dalam soal. Pada tahapan Polya, tahapan membaca soal dijelaskan secara implisit atau tidak tertulis. Kesulitan dalam membaca inilah yang nantinya berpengaruh pada kemampuan siswa pada bidang matematika, khususnya jika memasuki persoalan soal cerita matematika. Karena kemampuan membaca merupakan kemampuan awal yang penting untuk menentukan mampu atau tidak siswa dalam menyelesaikan soal matematika.

Geometri merupakan salah satu dari cabang mata pelajaran matematika yang penting untuk dipelajari, karena termasuk latihan berpikir logis dan kerja yang sistematis. Budiarto (2000) juga berpendapat bahwa tujuan pembelajaran geometri adalah untuk mengembangkan kemampuan berpikir logis, mengembangkan intuisi keruangan, menanamkan pengetahuan untuk menunjang materi yang lain, dan dapat membaca serta menginterpretasikan argumenargumen matematik. Materi tentang geometri merupakan salah satu materi dalam mata pelajaran matematika. Hal ini tertuang dalam Peraturan Menteri Pendidikan Nasional (Permendiknas) no 23 tahun 2006. Bahwa standar kelulusan mata pelajaran siswa SMP khususnya mata pelajaran matematika salah satunya adalah memahami bangun-bangun geometri, unsurunsur dan sifat-sifatnya, ukuran dan pengukurannya, meliputi: hubungan antar garis, sudut (melukis sudut dan membagi sudut), segitiga (termasuk melukis segitiga) dan segi empat, Teorema Pythagoras, lingkaran (garis singgung sekutu, lingkaran luar dan lingkaran dalam segitiga dan melukisnya), kubus, balok, prisma, limas dan jaring-jaringnya, kesebangunan dan kongruensi, tabung, kerucut, bola, serta menggunakannya dalam pemecahan masalah. Berdasarkan pengalaman peneliti saat mengajar baik di kelas maupun di luar kelas, geometri bagi siswa dianggap sebagai salah satu pokok bahasan yang cukup menyulitkan dikarenakan geometri lebih bersifat abstrak dan membutuhkan tampilan yang konkret atau dapat dibayangkan oleh siswa dalam proses belajar mengajar. Salah satu materi geometri yang dipelajari di tingkat menengah adalah bangun datar segiempat. Materi bangun datar segiempat merupakan materi prasyarat untuk mempelajari materi bangun ruang sisi datar dan kesebangunan. Oleh karena itu, jika siswa tidak menguasai materi bangun datar terutama segiempat maka akan menyebabkan kesulitan dalam mempelajari materi selanjutnya. Sebagai contoh, siswa melakukan kesalahan dalam menyelesaikan soal-soal kesebangunan karena siswa tidak menguasai materi prasyarat di antaranya adalah materi bangun datar segiempat.

Meskipun bangun datar sudah dipelajari siswa di tingkat sekolah dasar, tetapi kenyataanya masih ada siswa yang melakukan kesalahan dalam permasalahan bangun datar segiempat. Dalam penelitian Ningrum (2016) menjelaskan bahwa terjadi miskonsepsi pada sebagian besar siswa SMP tentang sifat-sifat bangun datar segiempat, kesalahan tersebut menjadi salah satu penyebab hasil belajar siswa SMP pada materi bangun datar segiempat menjadi kurang maksimal. Basuki (2012) juga berpendapat kesulitan siswa dalam geometri salah satunya adalah kurangnya pemahaman konsep tentang bangun datar.

Berdasarkan uraian tersebut, peneliti berusaha untuk mendeskripsikan tentang kesalahan yang dilakukan siswa dan faktor penyebab siswa melakukan kesalahan dalam proses pembelajaran. Sehingga peneliti tertarik untuk melakukan penelitian dengan judul "Analisis Kesalahan Siswa SMP Dalam Menyelesaikan Soal Cerita Berdasarkan Tahapan Newman Pada Materi Bangun Datar Segiempat".

Sartin (2005) berpendapat bahwa analisis merupakan suatu upaya untuk melihat, mengamati, mengetahui, memahami, menelaah, mengklarifikasi, mendalami, dan menginterpretasikan fenomena yang menjadi sasaran penelitian. Rosyidi (2005) berpendapat bahwa kesalahan merupakan penyimpangan terhadap hal yang dianggap benar atau prosedur yang telah ditetapkan sebelumnya. Dari pembahasan tentang analisis dan kesalahan tersebut. Maka, dapat disimpulkan bahwa analisis kesalahan adalah tindakan 
untuk mengamati sesuatu tentang penyimpangan terhadap suatu hal yang bernilai benar.

Soal cerita yang dimaksud sangat berhubungan dengan masalah kontekstual atau berkaitan dengan kehidupan sehari-hari, maka soal cerita adalah soal matematika yang terkait dengan permasalahan di kehidupan sehari-hari untuk dicari penyelesaiannya menggunakan kalimat matematika yang memuat bilangan, operasi hitung $(+, \quad, \div, \div)$ dan hubungan relasi $(=,<,>, \leq, \geq)$. Maka, dapat disimpulkan bahwa soal cerita merupakan soal yang disajikan dalam bentuk dari rangkaian kalimat membentuk sebuah cerita yang berkaitan dengan kehidupan sehari-hari dan mengandung suatu permasalahan yang harus dipecahkan. Soal cerita semacam ini penting untuk diberikan kepada siswa guna melatih perkembangan proses berfikir mereka secara berkelanjutan dalam rangka mencapai standar kompetensi yang telah ditetapkan, sehingga keberadaannya sangat diperlukan.

Segiempat adalah cabang dari materi geometri bangun datar. Segiempat mulai dipelajari siswa dari tingkat Sekolah Dasar (SD). Pada tingkat SMP, materi bangun datar terutama segiempat dipelajari kembali dengan standar kompetensi menganalisis sifat berbagai bangun datar segiempat berdasarkan sisi, sudut, hubungan antar sisi dan antar sudut, dan menurunkan rumus untuk menentukan keliling dan luas segiempat. Penelitian ini menggunakan materi luas dan keliling dari persegi dan persegipanjang.

Analisis kesalahan Newman atau Newman's Error Analysis adalah sistem yang dikembangkan oleh M. Anne Newman pada tahun 1977 yang digunakan untuk menganalisis kesalahan-kesalahan yang terjadi pada tugas yang diberikan ke siswa. Dalam metode ini, Newman mendefinisikan lima keterampilan membaca dan berhitung yang spesifik untuk membantu menemukan di mana kesalahan yang terjadi pada pekerjaan siswa ketika menyelesaikan suatu masalah berbentuk soal cerita.

Newman dalam White (2005:17) menjelaskan faktor penyebab siswa melakukan kesalahan dalam pemecahan masalah soal cerita. Adapun indikator penyebab kesalahan siswa sebagai berikut:

1. Kesalahan membaca soal (Reading)

Siswa digolongkan mengalami kesalahan dalam membaca soal jika siswa:

a. tidak mengetahui kata kunci pada soal

b. tidak mengetahui simbol-simbol pada soal

2. Kesalahan memahami soal (Comprehension)

Siswa digolongkan mengalami kesalahan dalam memahami soal jika siswa: a. salah dalam menuliskan apa yang diketahui pada soal

b. tidak lengkap dalam menuliskan apa yang diketahui pada soal

c. salah dalam menuliskan apa yang ditanyakan pada soal

d. tidak lengkap dalam menuliskan apa yang ditanyakan pada soal

3. Kesalahan transformasi soal (Transformation) Siswa digolongkan mengalami kesalahan dalam mentransformasi soal jika siswa:

a. salah dalam memberikan sketsa bangun datar sesuai pada soal

b. tidak menggunakan prosedur yang tepat

c. prosedur yang digunakan kurang lengkap

4. Kesalahan keterampilan proses (Skill process) Siswa digolongkan mengalami kesalahan dalam keterampilan proses jika siswa:

a. tidak lengkap dalam menuliskan prosedur pengerjaan

b. salah dalam melakukan perhitungan

5. Kesalahan penulisan jawaban (Encoding) Siswa digolongkan mengalami kesalahan dalam penulisan jawaban jika siswa:

a. salah dalam menuliskan jawaban akhir

b. menuliskan jawaban akhir dengan tidak lengkap

\section{METODE PENELITIAN}

Penelitian ini merupakan penelitian deskriptif-kualitatif. Bersifat deskriptif karena bertujuan untuk mendeskripsikan kesalahan-kesalahan yang dilakukan siswa berdasarkan tahapan analisis kesalahan Newman. Kualitatif karena karena peneliti meneliti kemampuan estimasi siswa dalam memecahkan masalah matematika terjadi pada kondisi yang alamiah dengan instrumen utama yakni peneliti sendiri. Sebagai instrumen utama, peneliti berhubungan langsung dengan subjek penelitian, menyesuaikan, mengamati kesalahan-kesalahan yang dilakukan siswa berdasarkan tahapan Newman.

Data yang diperoleh dari penelitian ini adalah data kesalahan-kesalahan yang dilakukan oleh siswa dalam menyelesaikan soal cerita bangun datar segiempat berdasarkan tahapan Newman. Dari hasil tes tulis, diperoleh ketiga subjek penelitian yang kemudian diwawancarai untuk mengetahui faktor-faktor penyebab kesalahan yang dilakukan subjek penelitian dalam menyelesaikan soal cerita bangun datar segiempat berdasarkan tahapan Newman. Dari jawaban yang telah diberikan oleh siswa, peneliti mendeskripsikan 
kesalahan dan faktor penyebab kesalahan siswa dalam menyelesaikan soal cerita bangun datar segiempat berdasarkan tahapan Newman.

\section{HASIL DAN PEMBAHASAN}

Tahap pertama pengambilan data penelitian berupa banyaknya kesalahan yang dilakukan oleh siswa saat menjawab pertanyaan yang diberikan oleh peneliti. Tes tulis yang diberikan berupa soal cerita tentang bangun datar segiempat sebanyak 2 butir soal dan dikerjakan secara individu dengan waktu pengerjaan maksimal dalam waktu 30 menit. Pada tahap pengambilan data ini, semua siswa tidak ada yang absen sehingga tidak ada kesulitan dalam proses pengambilan data yang pertama. Setelah melakukan analisis terhadap hasil tes tulis, peneliti kemudian memilih subjek penelitian sebanyak 3 siswa sesuai kriteria yang telah ditentukan.

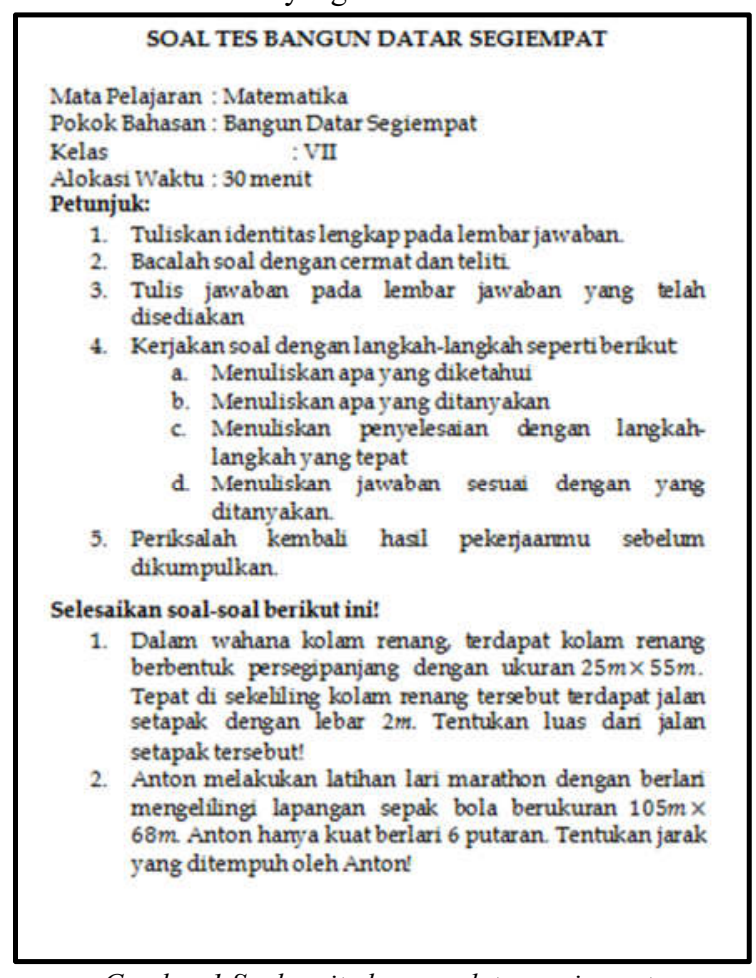

Gambar 1 Soal cerita bangun datar segiempat

Setelah dianalisis, siswa yang memiliki total kesalahan sedikit, belum tentu jawabannya benar. Ada soal yang tidak menyelesaikan sampai akhir dan ada pula siswa yang menuliskan jawaban akhir tanpa adanya proses pengerjaan. Saat siswa tidak menuliskan proses pengerjaan, maka dianggap tidak melakukan kesalahan, karena siswa tidak menuliskan apapun pada lembar jawaban sehingga tidak bisa dianalisis lebih lanjut. Sehingga berdasarkan hasil analisis tes tulis dan pertimbangan guru mitra maka dipilih 3 siswa yang akan dipilih untuk dijadikan subjek penelitian. Ketiga subjek penelitian tersebut disajikan dalam tabel berikut.
Tabel 1 Subjek penelitian terpilih

\begin{tabular}{|c|l|c|c|c|}
\hline No. & $\begin{array}{c}\text { Kode } \\
\text { Nama }\end{array}$ & No urut & $\begin{array}{c}\text { Banyak } \\
\text { kesalahan }\end{array}$ & kode \\
\hline 1 & AAS & 01 & 17 & SP1 \\
\hline 2 & ITMP & 16 & 14 & SP2 \\
\hline 3 & WMA & 31 & 14 & SP3 \\
\hline
\end{tabular}

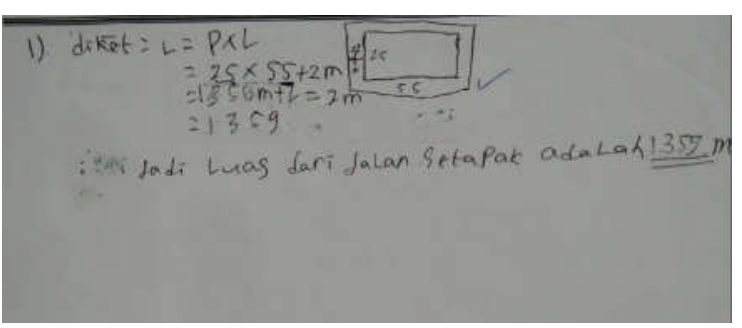

Gambar 2 Hasil jawaban SP1 nomor 1

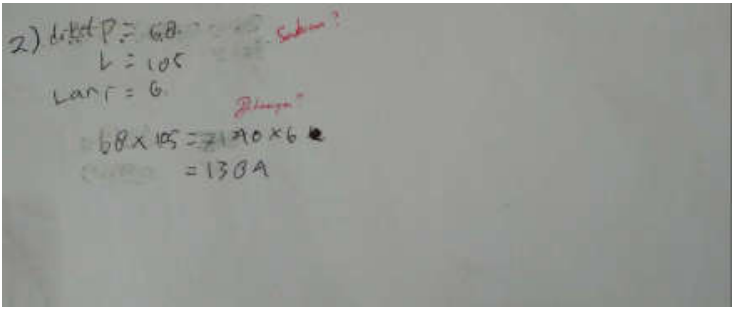

Gambar 3 Hasil jawaban SP1 nomor 2

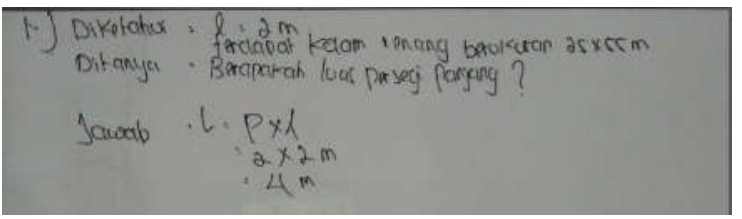

Gambar 4Hasil jawaban SP2 no 1

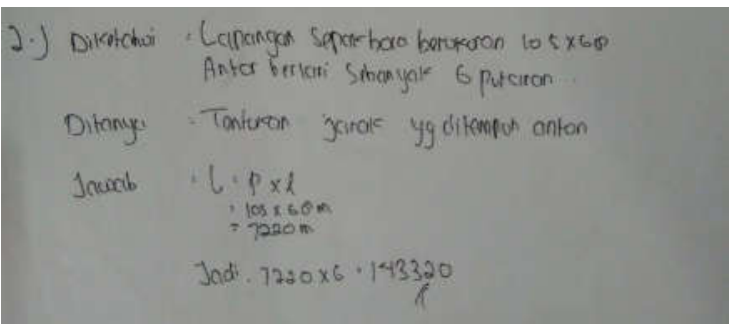

Gambar 5 Hasil jawaban SP2 no 2

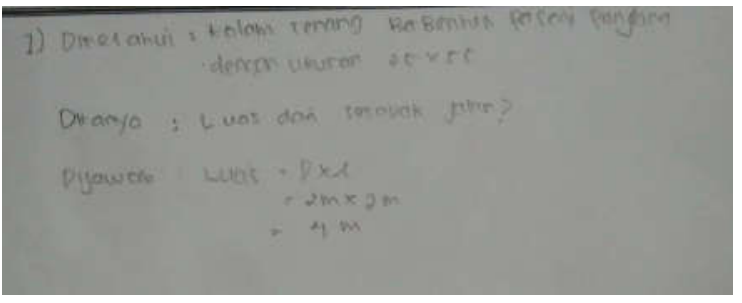

Gambar 6Hasil jawaban SP3 no 1 


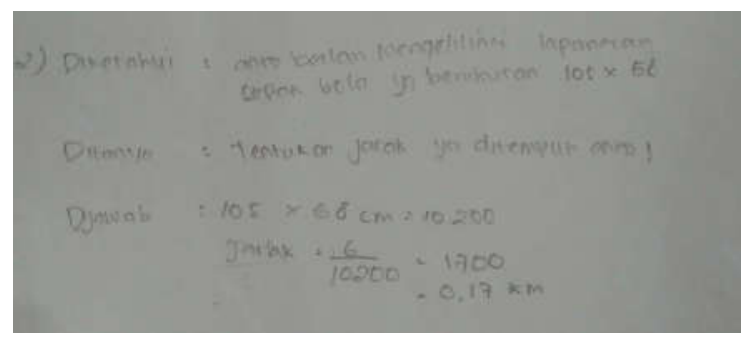

Gambar 7 Hasil jawaban SP3 no 2

Berikut perincian subjek penelitian yang terpilih,

1. AAS merupakan subjek penelitian pertama (SP1). SP1 merupakan subjek penelitian yang melakukan kesalahan terbanyak. Pada soal nomor 1, SP1 melakukan kesalahan pada beberapa tahapan, diantaranya membaca soal pada semua indikator, dalam memahami soal pada indikator $\mathrm{K} 2 \mathrm{a}$, transformasi soal pada indikator $\mathrm{K} 3 \mathrm{~b}$ dan $\mathrm{K} 3 \mathrm{c}$, keterampilan proses pada semua indikator dan penulisan jawaban akhir pada semua indikator. Untuk soal nomor 2, SP1 melakukan kesalahan pada semua tahap, diantaranya membaca soal pada indikator $\mathrm{K} 1 \mathrm{~b}$, memahami soal pada indikator K2b, K2c, K2d, transformasi soal pada semua indikator dan keterampilan proses pada semua indikator. Untuk penulisan jawaban akhir, SP1 tidak menuliskannya sehingga tidak dihitung dalam melakukan kesalahan.

2. ITMP merupakan subjek penelitian kedua(SP2). Sama seperti SP1, SP2 juga merupakan siswa yang banyak melakukan kesalahan pada saat tes tulis. Pada soal nomor 1, kesalahan yang dilakukan SP2 ada di semua tahap, antara lain tahap membaca soal indikator K1a, memahami soal indikator $\mathrm{K} 2 \mathrm{~b}, \mathrm{~K} 2 \mathrm{c}, \mathrm{K} 2 \mathrm{~d}$, transformasi soal pada indikator $\mathrm{K} 3 \mathrm{~b}, \mathrm{~K} 3 \mathrm{c}$ dan keterampilan proses pada semua indikator. Untuk penulisan jawaban akhir, SP2 tidak menuliskannya sehingga tidak dihitung dalam melakukan kesalahan. Pada soal nomor 2, SP2 melakukan kesalahan pada beberapa tahap, antara lain membaca soal pada indikator $\mathrm{K} 1 \mathrm{~b}$, transformasi soal pada indikator $\mathrm{K} 3 \mathrm{~b}, \mathrm{~K} 3 \mathrm{c}$, keterampilan proses pada semua indikator dan penulisan jawaban akhir pada semua indikator. Perbedaan yang mecolok dari SP1 dan SP2 terlihat pada pengerjaannya. SP2 meski masih kurang lengkap, tetap menuliskan apa yang diketahui dan ditanyakan pada soal nomor 1 dan 2. Sementara SP1 tidak menuliskan apa yang diketahui dan yang ditanyakan pada nomor 1 dan 2 .
3. WMA merupakan subjek penelitian ketiga (SP3). SP2 dan SP3 memiliki banyak kesalahan yang sama, hanya berbeda pada indikator subjek melakukan kesalahan. Pada soal nomor 1 SP3 melakukan kesalahan pada beberapa tahapan, antara lain, membaca soal pada semua indikator, memahami soal pada indikator $\mathrm{K} 2 \mathrm{~b}$, transformasi soal pada tahap K3b, K3c, keterampilan proses pada semua indikator. Untuk tahap penulisan jawaban akhir SP3 tidak menuliskannya, sehingga tidak dihitung dalam melakukan kesalahan. Pada soal nomor 2, SP3 juga melakukan kesalahan pada beberapa tahapan, antara lain membaca soal pada indikator K1a, memahami soal pada indikator $\mathrm{K} 2 \mathrm{~b}$, transformasi soal pada indikator $\mathrm{K} 3 \mathrm{~b}, \mathrm{~K} 3 \mathrm{c}$, keterampilan proses pada semua indikator. Untuk tahap penulisan jawaban akhir SP3 tidak menuliskannya, sehingga tidak dihitung dalam melakukan kesalahan. Letak kesalahan yang dilakukan SP2 dan SP3 hampir sama, yang membedakan hanya kesalahan pada tahap keterampilan proses.

\section{PEMBAHASAN}

Dari hasil analisis kesalahan siswa SMP Negeri 2 Nganjuk kelas VII-D dalam menyelesaikan soal cerita tentang bangun datar segiempat berdasarkan tahapan Newman, hasil analisis tersebut akan dibahas tentang jenis kesalahan yang dilakukan siswa dan penyebab siswa melakukan kesalahan.

1. Jenis kesalahan yang dilakukan subjek penelitian

Dari seluruh hasil jawaban yang telah dikerjakan siswa pada saat tes tulis, ditemukan beberapa kesalahan pada setiap tahap pengerjaan. Antara lain kesalahan pada tahap membaca soal, kesalahan pada tahap memahami soal, kesalahan pada tahap mentransformasi soal, kesalahan pada tahap keterampilan proses dan kesalahan pada tahap penulisan jawaban akhir.

a. Kesalahan dalam membaca soal

Kesalahan yang sering dilakukan oleh siswa dan banyak terjadi pada soal nomor 2. siswa salah dalam membaca penulisan “...berukuran $105 m \times 68 m$..." bukan sebagai ukuran panjang dan lebar persegi panjang melainkan sebagai operasi perkalian biasa. Beberapa siswa juga terbiasa tidak menuliskan satuan yang ada pada soal. Berdasarkan indikator pada tahap membaca soal, yaitu siswa tidak mengetahui kata kunci dan simbol-simbol 
pada soal. Maka, dapat disimpulkan bahwa siswa melakukan kesalahan pada tahap membaca soal.

b. Kesalahan dalam memahami soal

Pada tahap ini, hanya sebagian dari siswa yang melakukan kesalahan. Kesalahan yang sering dilakukan siswa yaitu kurang lengkap atau bahkan salah dalam menuliskan apa yang diketahui dan ditanyakan. Ada siswa yang sering tidak menuliskan satuan dari ukuran yang diketahui di soal. Ada juga siswa yang kurang tepat dalam menuliskan yang ditanyakan pada soal. Berdasarkan indikator pada tahap memahami soal, yaitu siswa kurang atau bahkan salah dalam menuliskan apa yang diketahui dan ditanyakan. Maka, dapat disimpulkan bahwa siswa melakukan kesalahan pada tahap memahami soal.

c. Kesalahan dalam mentransformasi soal

Pada tahap ini, terutama pada soal nomor 1, banyak siswa yang tidak membuat sketsa bangun datar dari soal yang sudah diketahui. Ada siswa yang berhasil menggambarkan sketsa bangun datar, tetapi salah dalam memilih rumus yang tepat untuk memecahkan masalah tersebut (Gambar 1). Pada soal nomor 2, semua banyak siswa yang tidak membuat sketsa dari soal tersebut, sehingga siswa salah dalam memilih rumus yang tepat untuk memecahkan soal tersebut. Berdasarkan indikator dalam mentransformasi soal, siswa tidak menggunakan prosedur atau rumus yang tepat, meskipun tepat tetapi subjek masih kurang dalam menuliskan prosedur atau rumus yang benar. Dapat disimpulkan bahwa siswa melakukan kesalahan dalam mentransformasi soal.

d. Kesalahan dalam keterampilan proses

Semua siswa, meski ada yang tepat dalam menentukan rumus, tetapi pada tahap selanjutnya semuanya melakukan kesalahan pada saat melakukan pengoperasian. Ada siswa yang salah memasukkan nilai yang sudah diketahui, dan ada pula siswa yang salah dalam melakukan operasi. Berdasarkan indikator dalam tahap keteampilan proses, siswa tidak lengkap dalam menuliskan prosedur dan salah dalam melakukan perhitungan. Maka, dapat disimpulkan bahwa siswa melakukan kesalahan dalam melakukan keterampilan proses.

e. Kesalahan dalam penulisan jawaban akhir

Dari semua hasil pekerjaan siswa, hanya ada beberapa pekerjaan yang sampai pada tahap ini. Meski berhasil menuliskan jawaban akhir, tetapi penulisan masih kurang lengkap dan jawaban masih kurang tepat. Berdasarkan indikator pada tahap penulisan jawaban akhir, siswa kurang lengkap bahkan salah dalam penulisan jawaban akhir. Maka, dapat disimpulkan siswa melakukan kesalahan dalam penulisan jawaban akhir.

2. Penyebab subjek penelitian melakukan kesalahan

Siswa melakukan kesalahan-kesalahan tersebut bukan tanpa alasan. Berikut adalah penyebab siswa melakukan kesalahan berdasarkan wawancara yang sudah dilakukan sebelumnya.

a. Penyebab kesalahan pada tahap membaca soal

Penyebab utama karena siswa kurang teliti dalam membaca soal dan siswa tidak belajar malam sebelum dilakukan tes tulis, sehingga subjek salah dalam membaca simbol pada soal.

b. Penyebab kesalahan pada tahap memahami soal

Ada siswa yang tidak terbiasa mengerjakan dengan prosedur diketahuiditanya-dijawab sehingga lupa dalam menuliskan apa yang diketahui dan ditanyakan.

c. Penyebab kesalahan pada tahap mentransformasi soal

Dalam mengubah soal cerita ke dalam sketsa bangun datar, ada siswa yang tidak terpikirkan dalam menggambarkan sketsa. Ada juga siswa yang tidak menggambarkan sketsa dengan alasan terburu-buru dan tidak sempat. Ada pula siswa karena belum begitu mengerti materi bangun datar, tidak membuat sketsa bangun datar.

Untuk menentukan rumus, banyak yang salah dalam menentukan rumus teruama pada soal nomor 2. Siswa banyak yang melakukan kesalahan dalam 
membaca kalimat “...berukuran $105 m \times$ $68 m$..." sehingga siswa beranggapan jika soal tersebut dapat dikerjakan dengan rumus luas persegi panjang. Ada siswa yang masih kurang begitu paham dengan materi bangun datar segiempat. siswa juga berpendapat, tidak bisa mengerjakan karena belum terbiasa dengan tipe soal seperti soal yang diberikan oleh peneliti.

d. Penyebab kesalahan pada tahap keterampilan proses

Kesalahan ini banyak dilakukan siswa karena kesalahan pemilihan rumus pada tahap sebelumnya. Juga ada siswa yang sudah benar rumus awalnya, tetapi salah saat memasukkan ukuran yang sudah diketahui sebelumnya. Siswa juga mengungkapkan kalau masih belum paham tentang rumus apa yang harus dipakai jika ada soal cerita seperti yang diberikan oleh peneliti.

e. Penyebab kesalahan pada tahap penulisan jawaban akhir

Siswa tidak terbiasa mengerjakan soal dengan prosedur diketahui-ditanyadijawab sehingga, meski mengerjakan sesuai prosedur, subjek hanya menuliskan jawaban pada saat proses perhitungan.

\section{PENUTUP}

\section{Simpulan}

Dari analisis data hasil pekerjaan dan wawancara subjek penelitian yang dibahas pada bab sebelumnya. Telah diperoleh jenis-jenis kesalahan yang telah subjek penelitian lakukan dan penyebab subjek penelitian melakukan kesalahan sebagai berikut:

1. Jenis kesalahan yang dilakukan siswa dalam mengerjakan soal cerita bangun datar segiempat berdasarkan tahapan Newman:

a. Kesalahan dalam membaca soal

1) Siswa sering tidak menuliskan satuan yang sesuai pada soal.

2) Siswa tidak bisa mengartikan kalimat “...berukuran $105 m \times 68 m$..." Bukan sebagai ukuran panjang dan lebar dari persegi panjang melainkan sebagai operasi perkalian biasa.

b. Kesalahan dalam memahami soal

1) Beberapa siswa melakukan kesalahan dengan cara menuliskan apa yang diketahui dan ditanyakan dengan kurang lengkap dan bahkan kurang tepat.

c. Kesalahan dalam transformasi soal
1) Banyak siswa yang tidak mengubah kalimat soal menjadi sketsa bangun datar sehingga kesulitan untuk mencari strategi atau rumus yang sesuai untuk memecahkan soal.

2) Ada siswa yang mampu untuk menggambarkan sketsa yang diminta, tetapi bingung dalam mencari rumus yang tepat untuk memecahkan soal.

d. Kesalahan dalam keterampilan proses

1) Selain karena kesalahan memilih rumus pada tahap sebelumnya, kesalahan yang dilakukan siswa adalah salah memasukkan ukuran panjang dan lebar yang sudah diketahui sebelumnya.

e. Kesalahan dalam penulisan jawaban akhir

1) Banyak siswa yang sanggup sampai tahap ini, tetapi selain kurang tepat dalam penulisannya juga ada yang salah dalam penulisan jawaban akhir.

2. Penyebab siswa melakukan kesalahan dalam mengerjakan soal cerita bangun datar segiempat berdasarkan tahapan Newman:

a. Kesalahan dalam membaca soal

1) Siswa kurang teliti dalam membaca soal

2) Siswa tidak belajar malam sebelum diadakan tes tulis

b. Kesalahan dalam memahami soal

1) Siswa belum terbiasa mengerjakan soal cerita dengan prosedur diketahui-ditanyadijawab sehingga lupa untuk menuliskannya.

c. Kesalahan dalam transformasi soal

1) Siswa tidak terpikirkan untuk membuat sketsa, ada juga siswa yang beralasan lupa dan buru-buru sehingga tidak sempat untuk membuat sketsa.

2) siswa belum begitu paham dengan materi luas dan keliling bangun datar juga karena siswa belum terbiasa mengerjakan tipe soal yang diberikan peneliti.

d. Kesalahan dalam keterampilan proses

1) Siswa belum begitu paham pada materi luas dan keliling persegi panjang sehingga siswa salah dalam memasukkan rumus.

e. Kesalahan dalam penulisan jawaban akhir

1) Selain karena kesalahan operasi pada tahap sebelumnya, siswa juga belum terbiasa dalam mengerjakan soal dengan prosedur diketahui-ditanya-dijawab sehingga hanya menuliskan jawaban pada saat proses perhitungan. 


\section{Saran}

Hasil penelitian ini diharapkan dapat memberikan sumbangan pemikirian sebagai suatu usaha untuk meningkatkan kemampuan siswa dalam bidang pendidikan khususnya pada bidang matematika. Saran yang dapat penulis sumbangkan dengan hasil penelitian ini adalah sebagai berikut:

1. Untuk mengatasi kesalahan dalam membaca dan memahami soal, guru sebaiknya meminta siswa untuk teliti dalam membaca soal dan jika perlu membaca kembali soal tersebut sehingga tidak ada informasi yang terlewatkan pada soal. Guru hendaknya membiasakan siswa untuk mengerjakan soal cerita dengan prosedur diketahui-ditanya-dijawab. Guru juga sebaiknya memastikan siswanya untuk memiliki pengetahuan tentang penyebutan dan arti dari simbol-simbol matematika.

2. Untuk mengatasi kesalahan dalam mentransformasi soal dan keterampilan proses, guru sebaiknya memastikan siswa untuk memahami materi dan rumus-rumus yang digunakan untuk memecahkan soal. Selain itu, siswa juga harus memperhatikan guru ketika mengajar dan mencatat materi penting yang disampaikan guru.

3. Untuk mengatasi kesalahan dalam penulisan jawaban akhir, guru sebaiknya meminta siswa untuk memeriksa kembali hasil pekerjaannya. Siswa juga sebaiknya memastikan jika hasil pekerjaannya telah sesuai dengan apa yang diminta soal.

4. Bagi peneliti lain, sebaiknya mengambil data di hari yang tepat. Sebagai misal, peneliti melakukan tes tulis di bulan Ramadhan. Sehingga saat melakukan tes tulis, peserta yang masih kelas VII SMP merasa malas dalam mengerjakan soal.

\section{Daftar Pustaka}

Abdussakir, 2010. Pembelajaran Geometri Sesuai Teori Van Hiele. El-Hikmah: Jurnal Kependidikan dan Keagamaan, Vol.7(2).

Basuki, N. R., 2012. Analisis Kesulitan Siswa SMK Pada Materi Pokok Geometri dan Alternatif Pemecahannya. Seminar Nasional Matematika dan Pendidikan Matematika, pp. 97-104.
Budiarto, M. T., 2000. Pembelajaran Geometri dan Berpikir Geometri. prosiding Seminar Nasional Matematika "Peran Matematika Memasuki Millenium III", 2 Nopember.

Ekawati, E., 2011. P4TKMATEMATIKA. [Online] Available at: http://p4tkmatematika.org/2011/10/peranfungsi-tujuan-dan-karakteristik-matematikasekolah/

[Diakses 2201 2020].

Ningrum, R. W., 2016. Miskonsepsi Siswa Smp Pada Materi Bangun Datar Segiempat Dan Alternatif Mengatasinya. Skripsi tidak diterbitkan. Surabaya: Universitas Negeri Surabaya.

Polya, G., 1973. How to solve it. 2nd penyunt. New Jersey: Princeton Science Library.

Putri, A. M., 2017. Analisis Kesalahan Siswa SMP Dalam Menyelesaikan Soal Cerita matematika Berdasarkan Tahapan Newman Serta Upaya Mengatasinya Menggunakan Scaffolding. Skripsi tidak diterbitkan. Surabaya: Universitas Negeri Surabaya.

Rahardjo, M. \& Waluyati, A., 2011. Pembelajaran Soal Cerita Hitung Campuran di Sekolah Dasar. Yogyakarta: PPPPTK Matematika.

Rosyidi, A. H., 2005. Analisis Kesalahan Siswa Kelas II MTs Al-khoiriyah dalam Menyelesaikan Soal Cerita yang Terkait dengan Sistem Persamaan Linear Dua Peubah. Tesis tidak diterbitkan. Surabaya: Perpustakan Pasca Sarjana Unesa.

Sartin, 2005. Analisis Kesalahan Siswa Kelas V Sekolah Dasar Dalam Menyelesaikan Soal Cerita Yang Memuat Pecahan Desimal. Tesis tidak dipublikasikan. Surabaya: Universitas Negeri Surabaya.

White, A. L., 2005. Active Mathematics In Classrooms Finding Out Why Children Make Mistakes And Then Doing Something To Help Them. Square One, December, 15(4), pp. 15-19.

White, A. L., 2010. Numeracy, Literacy and Newman's Error Analysis. Journal of Science and Mathematics Education in Southeast Asia, 33(2), pp. 129-148. 